\title{
ПОЛИТИЧЕСКАЯ СТАБИЛЬНОСТЬ
}

Бочарников И.В.

DOI: 10.7256/2305-560X.2016.2.17783

\section{ИСТОКИ И ЭВОЛЮЦИЯ ТЕРРОРА И ТЕРРОРИЗМА В МИРОВОЙ ПОЛИТИЧЕСКОЙ ПРАКТИКЕ}

\begin{abstract}
Аннотация. В статье анализируются истоки зарождения и эволюция террора и терроризма в мировой политической практике. На протяжении столетий данные явления представляли собой наиболее радикальные способы достижения и утверждения политического господства в рамках отдельных государственно-организованных обществ. Особым этапом их эволюции стала Великая Французская революция (1789 - 1794 годов), в ходе которой террор был институализирован в качестве принципа революционной целесообразности. В последующем этот стало обоснованием репрессий в отношении отдельных социальных групп и народов в ходе крупнейших социально-политических катаклизмов ХХ столетия. Методологической основой исследования является системный, структурно-функциональный, сравнительно-политический подходы, методы анализа, синтеза, индукции, дедукции, наблюдения. Как эфрективное средство достижения политического господства террор и терроризм использовались и ведущими странами мирового сообщества в реализации ими колониальной политики. Наиболее широко и массово методы террора использовались США в отношении коренного населения в ХІХ веке, Великобританией и другими колониальными державами, а также нацистской Германией в преддверии и в ходе Второй мировой войны.В современной политической практике террор и терроризм обрели характер глобальной проблемы и используются в процессе утверждения господства как отдельными государствами их альянсами, так и международными террористическими организациями.
\end{abstract}

Ключевые слова: политическая система, Россия, мировая политика, внешняя политика США, международные отношения, дипломатия, интересы, государство, безопасность, «цветные революции».

Abstract. The article analyzes the evolution and the origins of terror and terrorism in the world political practice. For centuries, these phenomena had been the most radical ways to gain and assert political dominance within certain state-organized societies.The French Revolution was a special stage of their development, which institutionalized terror as a principle of revolutionary expediency. Subsequently, it served as justification of repressions against certain social groups and peoples in the major social and political convulsions of the XXth century. The research methodology is based on the system, structural-functional and comparative-political approaches, the methods of analysis, synthesis, induction, deduction and observation. As an effective means of gaining political dominance, terror and terrorism were also used by the leading countries in their colonial policy. The methods of terror were actively used by the United States against indigenous peoples in the XIX century, by Britain and other colonial powers and Nazi Germany before and during World War II.In the modern political practice, terror and terrorism have become a global problem, and are used to gain and assert dominance by certain states and their alliances and international terrorist organizations. Key words: color revolutions, security, state, interests, diplomacy, international relations, US foreign policy, world policy, Russia, political system.

$\mathrm{T}$ еррор и терроризм известны человечеству с глубокой древности. Их проявления имели место уже в Античном мире, как на Древнем Востоке, так и в греческих и римских республиках. Так, один из древнейших литературных памятников - Ветхий Завет (кн. Исход, 5 - 12) свидетельствует о том, что более 2,5 веков назад на территории Египта в течение почти 3 месяцев были последовательно осуществлены десять террористических акций, вошедших в историю как «казни египетские». В них были применены биологические, бактериологические, экологические, химические и другие средства массового поражения. Делалось это для устрашения египетского фараона, державшего, как следует из Завета, в рабстве еврейский этнос. Эти действия, как отмечается
Ветхим Заветом, проведенные Моисеем и Аароном и имевшие конечной целью освобождение «детей Израилевых» и, соответственно, оправдывались в последующем как справедливые, несмотря на то, что огромные жертвы в результате этих акций понесли другие жители Египта [18].

История Античного мира, особенно римского периода, насыщена примерами проявления террора. Как, правило, осуществлялся он господствующей верхушкой по отношению к своим внутренним и внешним противникам.

Так, наибольшую известность в этот период получила политика диктатора Суллы (82 - 79 годы до н. э.) в рамках которой, проводились массовые уничтожения представителей враждебных группировок. В этот же период были введены и печаль- 
но знаменитые проскрипции - списки лиц, которых всякий римлянин имел право убить без суда.

В последующем террор, как метод физического уничтожения политических оппонентов, широко использовался во времена Первого и Второго римских триумвиратов $(60-53$ и 43 - 36 годы до н. э.). Используя его, Помпей, Красс, Цезарь и другие диктаторы преследовали цель не только уничтожить своих противников, но и устрашить, заставив отказаться от задуманного. Примечательно, что одной из наиболее известных жертв терроризма в Античном мире стал и сам Ю. Цезарь.

Возведенный в ранг государственной политики, террор, нередко использовался как средство управления обществом и подавления политического противника, о чем свидетельствуют методы управления, и в частности усмирения многочисленных волнений рабов и населения (только после поражения восстания Спартака было распято на крестах около 6 тысяч восставших).

Вместе с тем тот ранний террор, за редким исключением, не носил еще массового, системного характера, его цели открыто не декларировались, а устрашение служило фоном и играло второстепенную роль в физическом устранении политических оппонентов.

Следует отметить, что терроризм в Античном мире осуществлялся не только органами власти «сверху», но и оппозиционными им структурами, представителями радикальной части населения древнейших государств. При этом, так называемый «терроризм снизу» развивался в самых разнообразных формах от религиозных движений на уровне сект и ответвлений от основных религий до восстаний и бунтов.

Так, исторические источники свидетельствуют о деятельности террористической религиозной секты сикариев на территории Палестины в 77 году н.э., которая действовала дерзко, убивала людей короткими ножами в дневное время на рынках, площадях, пользуясь неразберихой толпы. Кроме того, сикарии осуществляли поджоги зернохранилищ, выводили из строя системы водоснабжения. При этом сикарии оправдывали и свою смерть, и смерть людей мученичеством во имя Бога. Государство как институт они не признавали $[14,1981]$. Схожая тактика в настоящее время просматривается в деятельности современных террористических группировок на Ближнем Востоке. При этом террор в виде подрывов террористов самоубийц и в нынешнее время рассматривается как великомученическое деяние - джихадизм, предполагающее самопожертвование ради торжества идеалов Ислама.

К началу I века н.э. относится и зарождение религиозно мотивированного терроризма, наиболее отчетливо проявляющего в настоящее время.
Так, в 259 году во время богослужения римлянами, исповедовавшими тогда в основном еще язычество, были убиты христианский епископ Сикст II с шестью диаконами. Под впечатлением этой расправы над первыми христианами епископская кафедра пустовала почти в течение года. В дальнейшем репрессии со стороны государства продолжались с разной интенсивностью. В первом десятилетии IV века из армии были уволены лица, исповедовавшие христианство, а затем последовал приказ разрушить церкви, уничтожить богословские книги и требовавший отречения от христианской религии под страхом лишения гражданских прав. Когда в Сирии и Каппадокии в ответ на эти меры начались волнения, римский император приказал арестовать все духовенство, заковать в кандалы и держать до тех пор, пока они не принесут жертву языческим богам. В 304 году принимается эдикт, в соответствии с которым все городское христианское население должно было принести языческим богам жертвы под угрозой пыток и смертной казни [12, 20-21].

Справедливости ради следует отметить, что террор широко использовался и ранними христианскими обществами. Гонения, которыми подвергались христиане, в полной мере были обращены против язычников с момента утверждения в Римской империи в 473 году христианской религии в качестве государственной. В дальнейшем это нашло развитие в крестовых походах, когда под угрозой смерти происходило массовое насильственное обращение в христианскую веру многочисленных народов. Но в еще большей мере под категорию террора подпадали действия инквизиции, по приговорам которой в Европе за период с XV века до начала XIX столетия, по подсчетам историков, было уничтожено до 10 - 12 миллионов [1].

Широкое развитие в этот период также тайные организации, руководимые крупными феодалами и использующие убийство своих противников как средство политической борьбы. Ярким представителем такой организации являются ассасины. Эта сектантская организация, или орден неоисмаилитов-низаристов, образовалась в Иране в конце II в. с центром в замке Аламут. Основателем организации был Хасан ибн Сабба, превративший террор в хорошо продуманную стратегию, имевшую большой политический эффект.

В рамках этой деятельности ассасины совершали набеги на Сирию, убивали префектов, губернаторов, калифов. В качестве оружия террора ассасины использовали только кинжал - как ритуальное орудие.

Для совершения террористических акций ассасины использовали обученных и дисциплинированных воинов, готовых умереть за веру по 
первому приказу Хасан ибн Сабба. Эти «боевики» получили название фидави (т.е. обреченные), в другой транскрипции - хашашины. В качестве средства единения и воодушевления использовались как религиозные догмы, так и вполне материальные - наркотики.

Примечательно, что метод хашашинов - подготовка смертников с помощью наркотических средств - используется и в настоящее время в некоторых исламских экстремистских организациях, в том числе и так называемым «Исламским государством».

В Средние же века подобные методы использовали религиозные секты и организации не только в Персии и на Ближнем Востоке, но и в Индии и Китае. Таким образом, организации, подобные сикариям, фидаям, ассасинам и другим, можно считать предшественниками регулярного оппозиционного и сепаратистского террора - неизменного спутника всех революционных потрясений XVII - XX веков в Англии, Франции, а затем в Российской империи, странах Латинской Америки и Африки, а также религиозных и иных конфликтов.

Как средство достижения и реализации власти, в том числе на государственном уровне терроризм в последующем нашел достаточно широкое применение практически во всех странах. Особым этапом в эволюции терроризма стала Великая Французская революция. Ее значение состоит в том, что она способствовала институализации террора в качестве важнейшего средства завоевания и удержания политического господства.

Именно это предопределило объединение в 1792 году двух ведущих политических группировок революционно Франции - жирондистов и якобинцев, с целью свержения «с помощью устрашения и приведения в ужас» кабинета министров при короле Людовике XVI. Тогда террор воспринимался и использовался идеологами французской революции в контексте восстания народных масс и ниспровержения деспотического режима $[20,54]$. Однако после захвата власти в стране, французские революционеры вовсе не отказались от террора, а обратили его против собственных граждан.

Уже 2 октября 1792 года был создан особый орган для проведения чрезвычайных мер по защите Республики от внешних и внутренних врагов - Комитет общественной безопасности. Была существенно упрощена судебная процедура, а политическим преступлением считалось все, что подрывало позиции Конвента $[20,59]$. Таким образом, проявился и главный принцип террора - уничтожение невиновных для того, чтобы запугать тех, кто еще не уничтожен.

В последующем этот принцип стал определяющим в деятельности различного рода радикаль- ных и экстремистских групп, которые оправдывали ее приверженностью революционным идеалам свободы, равенства, справедливости и братства.

Именно таким образом, например, происходило утверждение большевистской диктатуры пролетариата после Великой Октябрьской революции 1917 года.И хотя проявления терроризма имели место в России задолго до революции, именно после нее террор стал частью государственной политики по подавлению любых проявлений недовольства и критики пришедшего к власти режима. Формально же это было закреплено 2 сентября 1918 года в обращении Я. Свердлова в ВЦИК и подтверждено Постановлением Совнаркома РСФСР от 5 сентября 1918 года как ответ на покушение на В.И. Ленина 30 августа, а также на убийство в тот же день председателя Петроградской ЧК В. Урицкого. Согласно данному Постановлению «обеспечение тыла путём террора является прямой необходимостью», республика освобождается от «классовых врагов путём изолирования их в концентрационных лагерях», «подлежат расстрелу все лица, прикосновенные к белогвардейским организациям, заговорам и мятежам». К категории классовых врагов были отнесены не только те, кто не принял Советскую власть по идеологическим мотивам, но и целые социальные слои населения страны: дворянство, предприниматели, духовенство, казачество, офицерский корпус, зажиточные крестьяне и т.д. Все они в одночасье оказались «вне закона» и в любой по момент могли быть подвергнуты репрессиям вплоть до физического уничтожения. Это и происходило в реальности, начиная буквально с первых постреволюционных дней, и вплоть до окончания гражданской войны и подавления антибольшевистских восстаний в Кронштадте, на Тамбовщине, Дону, Кавказе и в других регионах страны.

Аналогичным образом террор осуществлялся и противниками Советской власти в рамках, так называемого «белого террора». Общее же число жертв этой политики террора, осуществлявшейся и сторонниками, и противниками Советской власти, по данным исследователей, составило порядка 1,5 млн. человек [11]. И это не считая, всех жертв того времени: погибших на полях гражданской войны, умерших от голода и болезней в этот период, а также вынужденно эмигрировавших за ее пределы.

Логическим продолжением политики «красного террора» стали репрессии 30-50-х годов, число жертв которых составило согласно имеющимся архивным данным, порядка 1,76 млн. человек [15]. И, хотя, по мнению ряда исследователей, эти данные явно занижены, тем не менее, они свидетельствуют о масштабах терроризма, развернувшегося под эгидой органов государственной власти в интересах обеспечения политического господства. 
Примечательно, что одной из наиболее значимых особенностей репрессий в СССР стало то, что их первыми жертвами стали именно те, кто инициировал и непосредственно осуществлял «красный» террор в России - так называемая «ленинская гвардия». Это в полной мере подтвердило справедливость слов одного из инициаторов террора периода Великой Французской буржуазной революции Ж. Дантона, произнесенных им перед своей казнью - «Революция пожирает своих детей» [21]. Эти слова, ставшие, в конечном итоге, пророческими отражали вполне объективную закономерность того, что рано или поздно жертвами террора становятся не только те против кого он направлен, но и сами творцы террора.

В последующем эта закономерность не раз подтверждалась мировой политической практикой, в том числе в ходе другой «великой» революции - Культурной (1966 - 1976 годы) в КНР, в рамках которой осуществлялось масштабная перестройка идеологических и социально-политических основ развития китайской государственности того времени.

Количество жертв той революции превысило несколько десятков миллионов человек. И вновь жертвами, развернувшегося в ходе нее, террора стали его инициаторы и исполнители, хотя, конечно же, основную часть жертв составили ни в чем не повинные и весьма далекие и от политики, и от революции люди.

Это и является отражением, той самой главной закономерности, согласно которой любые революционные потрясения неизбежно влекут за собой ужесточение политического режима, сопровождаемого террором и насилием. Жертвами же этого революционного террора, закономерно становятся те, кто искренне верит в его революционную целесообразность и непосредственно участвует в нем.

Подтверждена эта формула и в ходе революционных процессов в рамках, так называемой «арабской весны». Жертвами данной «весны», согласно данным, обнародованным в декабре 2015 года на Арабском стратегическом форуме стали более 1,3 млн. человек [3]. И это не считая миллионов беженцев и вынужденных переселенцев, покинувших места своего проживания и осаждающих в настоящее время страны Евросоюза.

Проявляется данная закономерность и в рамках одной из наиболее резонансных революций современности - «майданной» - на Украине. Граждане этой страны, движимые идеалами справедливости и надеждой на интеграцию с Евросоюзом во многом способствовали тому, чтобы к власти пришел ультранационалистический режим, взявший на вооружение методы репрессий и террора в отношении собственного народа. За неполные два года после прихода к власти «евроориентированного» режима на Украине, по всей видимости, уже нет той нормы гуманитарного права, которая бы не была нарушена в ходе продолжающейся карательной операции на Донбассе, а также подавления протестов в других регионах Украины. Перечень преступлений против человечности давно уже превзошел аналог подобных обвинений Нюренбергского трибунала. Одесская Хатынь 2 мая 2014 года, систематические обстрелы шахтерских городов и поселков из тяжелого вооружения, в том числе баллистическими ракетами, преднамеренное разрушение инфраструктуры обеспечения жизнедеятельности населения Донбасса, похищения, пытки, издевательства, внесудебные расправы, массовые убийства, - все это не только нацистское 70-летнее прошлое, это еще и реалии современной Украины [2].

Общее число жертв за неполные два года правления режима украинских ультранационалистов составило, по заявлению постоянного представителя России при ОБСЕ А. Лукашевича, более 9 тыс. человек (9098 человек), более 20 тысяч человек - пострадали [13].

Таковы далеко не полные результаты той политики террора, развернутого на территории Украины, режимом новых революционеров. Все это также может быть отнесено к политике государственного терроризма, осуществляемого под прикрытием лозунгов о демократии и защите идеалов революции.

Следует отметить, что далеко не всегда террор осуществлялся по идеологическим мотивам. Нередко его методы применялись и применяются для реализации вполне прагматических целей и задач. Особую лепту в это внесли Соединенные Штаты, созданные почти 250 лет назад в борьбе за независимость от своей метрополии - Великобритании. Одним из первых правовых актов США стала Декларация о независимости (1776 год), в которой провозглашалось, что «все люди сотворены равными, и все они наделены Творцом неотъемлемыми правами, к числу которых принадлежит жизнь, свобода и стремление к счастью. Для обеспечения этих прав учреждены среди людей правительства, облекаемые справедливой властью с согласия управляемых...» [8]. Эти положения были подкреплены и Биллем о правах 1791 года.

Таким образом, в мировой практике были закреплены демократические права и свободы граждан, определены гарантии их реализации. В то же время положения этих актов, проповедовавшие свободы и равенство для «всех и всегда», не распространялись на представителей коренного населения страны - индейцев, равно как и на завезенных с Африканского континента рабов. 
Напротив, именно в период утверждения демократии в США появилось утверждение «хороший индеец - это мертвый индеец». Авторство этой крылатой фразы принадлежит американскому генералу Ф. Шеридану - одному из идеологов и наиболее рьяных исполнителей политики геноцида индейцев [22].

Индейцев спаивали алкоголем, натравливали друг на друга; обманывали, нарушали договоры; силой отнимались земли и оттесняли их дальше вглубь материка на неплодородные земли. С этой целью, например, в 1867 году в США был принят Закон о переселении индейцев в резервации, создававшиеся в непригодных для сельского хозяйства местах.

Актом террора с полным основанием можно отнести и целенаправленное широкомасштабное истребление бизонов с тем, чтобы лишить индейцев охоты и добывания пищи. По этому поводу печально упоминавшийся выше Ф. Шеридан в конгрессе США предлагал даже учредить специальную медаль, поскольку, «охотники за бизонами, - по его мнению, - сделали больше для решения острой проблемы индейцев, чем вся регулярная армия за последние 30 лет» [17].

Массовое распространение получило также практика скальпирования. Во многом это было связано с тем, что колонисты предлагали щедрое вознаграждение за скальпы врагов - как индейцев, так и своих соплеменников.

В некоторые периоды власти того или иного штата готовы были платить за трофей свыше \$100! Естественно, скальп воина стоил дороже, чем женский, детский или пожилого человека, но это мало кого останавливало из охотников за подобной добычей. При этом скальпированием на территории Северной Америки занимались не только индейцы, но и европейцы! Причем иногда индейцы содрогались от жестокости завоевателей [4].

Все эти направления «решения индейского вопроса» с полным основанием должны быть отнесены к категории геноцида, и, соответственно, политике террора, осуществлявшейся под эгидой государства - Соединенных Штатов. Целью этой политики было осознанное уничтожение людей по этническому признаку.

Справедливости ради следует отметить, что аналогичную политику этнических чисток Североамериканского континента проводили и другие не менее просвещенные государства - Франция и Великобритания, но именно в США это политика получила характер широкомасштабной кампании уничтожения коренного населения. Ее результатом стало то, что уже к началу XX века оно составляло менее 1\% населения страны. Общее же количество жертв коренного населения, по подсчетам американских ученых составило не менее 15 млн. человек [9].

Не оставалось стороне от применения различных форм террора на государственном уровне и другая, не менее «просвещенная» держава англосаксонского мира - Великобритания. Истребление индейцев Северной Америки началось задолго до образования США. У истоков этой политики геноцида стояли английские колонисты. И подобного рода политика осуществлялась ими не только на Североамериканском континенте, но и в других регионах Планеты - в Австралии, Новой Зеландии, в Африке.

Примечательно, что именно англичанам принадлежит изуверское изобретение начала XX века концентрационные лагеря, появившиеся в ходе англо-бурской войны 1899 - 1902 годов.

Первые концентрационные лагеря появились еще в период гражданской войны в США, но именно в ходе англо-бурской войны по распоряжению главнокомандующего британскими войсками лорда Г. Китченера, впервые задолго до нацистов, была применена бесчеловечная система концентрационных лагерей в отношении гражданского населения.

Этими концентрационными лагерями, получившими издевательское название «refuge» («убежище», «место спасения») была покрыта вся территория бурских республик - Трансвааль и Оранжевой. По различным данным в них содержалось порядка 200 тыс. человек гражданского населения - 120 тыс. буров и 80 тыс. африканцев [6]. Жертвами этих «refuge» за период с 1899 по 1902 годы стали 27 тыс. буров, в том числе 22 тыс. детей и от 14 до 20 тыс. африканцев. Именно так британцы и побеждали в той войне.

Все эти виды террора в отношении коренного населения реализовывались и иными колониальными странами: Францией, Испанией, Голландией, Бельгией и другими, но масштабы британского терроризма в отношении покоренных стран и народов, значительно превосходят их «достижения» в этой сфере.

Рассматривая основные этапы террора и терроризма в контексте эволюции человеческой цивилизации, нельзя не упомянуть два наиболее эпохальных события XX века - Первую и Вторую мировые войны. Поводом для каждой из них явились специальные террористические действия. В первом случае таковым стала террористическая акция в отношении австрийского эрц-герцога Фердинанда в г. Сараево в июле 1914 года, а, во втором диверсионно-террористическая операция под руководством О. Скорцени, выразившаяся в захвате радиостанции в польском городе Гельвенице в августе 1939 года. Террористические действия, 
в данном случае, сыграли роль детонатора конфликтов глобального масштаба - Первой и Второй мировых войн.

В ходе этих глобальных конфликтов терроризм получил свое дальнейшее развитие. Но, если в ходе Первой мировой войны террор в отношении гражданского населения был все же эпизодичен (наиболее известным его проявлением стал геноцид армян, осуществленный Турцией в 1915 году [10]), то Вторая мировая война, развязанная нацисткой Германией, по сути, была ее войной на истребление всех, кто не относился к так называемой, «арийской» расе.

Следует отметить, что пришедшие к власти в 1933 году в Германии нацисты в полной мере использовали террор в отношении граждан, как своего, так и покоренных европейских, государств.

Особое место в этой политике террора занимала система концентрационных лагерей. Первоначально они создавались для изоляции политических оппонентов нацистов - антифашистов и, в первую очередь, коммунистов и социал-демократов. Первый такой концентрационный лагерь был создан близ Дахау в марте 1933 года, то есть через два месяца после прихода нацистов к власти. К началу же Второй войны в тюрьмах и концентрационных лагерях Германии находились порядка 300 тысяч немецких, австрийских и чешских антифашистов [16]. В последующие годы гитлеровская Германия на территории оккупированных ею европейских стран создала гигантскую сеть концентрационные лагерей, превращенных в места организованного систематического убийства миллионов людей.

Общее количество концентрационных лагерей, их филиалов, тюрем, гетто в оккупированных странах Европы и в самой Германии, где в тяжелейших условиях содержались и уничтожались различными методами и средствами люди 14033 пункта. Из 18 млн. граждан стран Европы, прошедших через лагеря различного назначения, в т.ч. и концентрационные лагеря, было уничтожено более 11 млн. человек [16]. Общее же число жертв нацистов, уничтоженных ими на оккупированных территориях составило более 46 млн. человек, при том, что боевые и санитарные потери воюющих государств составили порядка 25 млн. человек.

Послевоенный период характеризуется, с одной стороны, формированием системы биполярного противостояния, а с другой, - эскалацией террористической угрозы в большинстве регионов мира.

В наибольшей степени конфликтогенный потенциал терроризма проявился с начала 60-х годов XX века, когда целые регионы мира были покрыты зонами и очагами активности различных по своей ориентации террористических организаций и групп.
Наиболее активными в этот период были праворадикальные и леворадикальные экстремистские организации.

Под антиимпериалистическими и прокоммунистическими лозунгами выступали: в Испании баскская организация ЭТА, основанная в 1959 году; во Франции - организация «Прямое действие»в 1979 году; в Германии - «Фракция Красной армии» - конец 1960-х годов; в Италии - «Красные бригады» - 1970-ые годы; в Греции - организация «Народная революционная борьба» - с 1974 года; в Японии в 1970 году появилась т.н. «Красная армия Японии», в основу идеологии которой заложена смесь лозунгов марксизма и традиционного японского милитаризма.

Наиболее известными праворадикальными экстремистскими организациями, осуществлявшими террористические акции в этот период являлись бритоголовые в Великобритании, различного рода неонацистские группировки как в самой Германии, так и в ряде других государствах. В США такой организацией, например, стала Ку-клус-клан.

В этот же период широкую известность получила и созданная в Турции группировка правого толка «Серые волки», насчитывающая до 30 тыс. членов и имеющая 80 филиалов в разных странах мира. Не ограничиваясь террором против прокоммунистических деятелей, она организовала теракт против папы Иоанна Павла II.

Немало международных террористических организаций обосновывали свою программу действий лозунгами национально-освободительной борьбы. К ним относится «Ирландская республиканская армия» (Великобритания) - католическая организация, основанная в 1914 года и активно действующая с 1969 года под лозунгом воссоединения британской провинции Ольстер с Ирландией.

Среди других наиболее известных групп экстремистов, использующих террор в качестве основного способа борьбы, следует назвать: «Палестинский исламский джихад» на оккупированных Израилем территориях; «Гамайя исламия» («Исламская группа») в Египте; «Вооруженная исламская группа» в Алжире; международная группа «Барбар Халса» в Индии; «Тигры освобождения Тамил Илама» в Шри-Ланке. Таков далеко не полный перечень международных террористических организаций. Всего же в этот период было сформировано порядка 500 нелегальных террористических организаций. С 1968 по 1980 годы ими было совершено около 6700 террористических актов, в результате которых погибло 3668 и ранено 7474 человека [5].

В значительной мере эскалации террористической угрозе и формированию феномена международного терроризма способствовала глобальная 
военно-политическая конфронтация в 60-80-ые годы XX столетия. Вполне очевиден тот факт, что международный терроризм активно взращивался в рамках данного процесса. Справедливости ради следует отметить, что именно под патронажем и при непосредственной поддержке США формировались известные ныне наиболее мощные террористические организации «Аль-Каида» и движение «Талибан» в Афганистане [23][24]. Кому не памятны в этом плане слова Р. Рейгана о том, что США нужен не один, а семь «афганистанов», пылающих вдоль границ СССР. Конечно же, Афганистан и события в нем сыграли свою роль в процессе распада СССР. И в этом плане историческая миссия Рейгана, безусловно, была выполнена. Но при этом «джин», которого выпустили под реализацию данной исторической миссии, обратно «лезть в кувшин» не захотел, предъявив свои собственные претензии на участие в мировых политических процессах. И поэтому вполне закономерен тот факт, что в конечном итоге острие международного терроризма было направлено и против самих США. Неслучайно, что именно в Афганистане нашел свой приют и объявленный руководством США террористом №1 Усама бен Ладен. А оставшиеся после ухода СССР из Афганистана 8-15 тыс. боевиков-террористов в последующем стали опорой развития терроризма на Ближнем Востоке и в Центрально-азиатском регионе [25][26].

Нельзя в этой связи не упомянуть и о событиях 11 сентября 2001 года, о которых ряд исследователей говорят как о начале эры супертерроризма, совпавшей по временным параметрам с очередной перестройкой существующего миропорядка.

В результате данной, не имевшей прежде аналогов, комбинированной террористической акции, погибло почти 7 тысяч человек. Из них 266 авиапассажиров погибли в захваченных самолетах, более 200 американских граждан - в Вашингтоне, где один из захваченных террористами самолет был обрушен на Пентагон, 6333 человека - во Всемирном торговом центре в Нью-Йорке (большинство из них считаются пропавшими без вести).

И хотя сама по себя акция вызывает очень много вопросов относительно истинных участников и заказчиков терактов, тем не менее, весьма примечателен вывод Доклад представленный американскому Конгрессу по расследованию причин и обстоятельств террористической акции 11 сентября 2001 года, в котором констатируется, что террористическая сеть Аль-Каида, взявшая на себя ответственность за налет на жизненно-важные центры страны по существу была создана самими же США.

Все это свидетельствует о том, что одной из причин эволюции международного терроризма и его современного влияния в мире является сама деятельность ведущих мировых держав в период биполярного противостояния, а точнее их руководящих кругов, исповедовавших принцип, что политика - это искусство возможного, а для реализации жизненно важных целей все средства хороши. Важнейшим следствием этого стала трансформация терроризма в одно из наиболее значимых социально-политических явлений, определяющих динамику и содержание политических процессов, в том числе, на международном и глобальном уровнях.

Таким образом, международный терроризм постепенно становится долговременным фактором в современной политической жизни и, более того, он оказался непосредственно связанным с проблемой выживания человечества. При этом очевидно, что международный терроризм это - не просто самая современная форма террористической деятельности. Это - качественно новое явление в сфере террора. С известными прежде его формами оно связано разве что названием да убийствами людей. Кем бы они ни практиковались (отдельными лицами, разного рода организациями) террор считался одним из средств достижения политических целей в, как правило, экстремальных ситуациях и носил не перманентный, а эпизодический характер.

Качественный перелом в террористической деятельности наступил с подключением к ней институтов государства и превращением ее в метод и средство реализации государственной политики. Благодаря силе, средствам и возможностям государства террор закономерно преобразовался в терроризм. Использование же его как орудия глобальной политики закономерно породило и явление, известное ныне как международный терроризм.

\section{Библиография:}

1. Андреева Е. Без пролития крови - инквизиция. http://www.bibliotekar.ru/andreeva/12.htm.

2. Бочарников И.В. Осторожно, тоталитаризм http://ria.ru/zinoviev_club/20141030/1030945513.html.

3. В Дубае подсчитали стоимость последствий «Арабской весны» http://деловыеэмираты.pф/news/uae-news. php?ELEMENT_ID=63334.

4. Геноцид коренного населения Америки в США http://namtaru.ru/genotsid/254.html

5. Гушер А.И. Проблема терроризма на рубеже третьего тысячелетия новой эры человечества http://old.nasledie. ru/terror/25_8/article.php?art=3.

6. Давидсон А.Б., Филатова И.И. Англо-бурская война и Россия // Новая и новейшая история, 2000, №1. http:// zadocs.ru/voennoe/11521/index.html?page $=2$

7. Диннон Р. Американский Индеец: Первая Жертва. http://www.pravda.ru/world/2005/5/82/337/19724_GENOCID.html. 
8. Декларация независимости. Конгресс, 4 июля 1776 г. http://www.hist.msu.ru/ER/Etext/indpndnc.htm.

9. Демографическая катастрофа индейцев Америки https://ru.wikipedia.org/wiki.

10. День памяти геноцида армян в Османской империи в 1915 году http://ria.ru/spravka/20150424/1060167106. html\#ixzz3x8VW0E2U.

11. Литвин А.Л. Красный и белый террор в России. 1918 - 1922 гг. http://www.e-reading.club/bookreader.php/1004379/ Litvin_Aleksey_-Krasnyy_i_belyy_terror_v_Rossii._1918-1922_gg..html\#n_3

12. Лозинский С. Г. История папства. 3-е изд. М., 1986. С. 20-21.

13. Лукашевич: Россия обеспокоена политическим экстремизмом на Украине http://www.tvc.ru/news/show/ id/82637/.

14. Малый энциклопедический словарь: В 4-х т.: Репринт. воспроизвед. издания Брокгауза-Ефрона. М: Терра, 1997. T. 4. С. 1891.

15. Масштабы сталинских репрессий в оценках советских и современных российских исследователей http://bg.sutr. ru/journals_n/1356460361.pdf.

16. Нацистские концлагеря в годы Второй мировой войны. Справка. http://ria.ru/spravka/20100427/227000409. html\#ixzz3x8ZSTnOo

17. На чем стоит Америка http://www.rospisatel.ru/novosti/nov12.htm

18. Нечипоренко О.М. Терроризм - древний и смертельно опасный спутник человечества / Мировое общество против глобализации преступности и терроризма. Международная конференция. М., 2001. Режим доступа: http:// www. waaf. ru.

19. Овсянникова О.А. Технологии переформатирования общественного сознания посредством языковой и конфессиональной дискриминации (на примере Украины) // Конфликтология / nota bene. - 2015. - № 4. - C.424-429.

20. Одесский М.Ф., Фельдман Д.М. Поэтика террора. - М.: РГГУ, 1997. - C.54-60.

21. Словарь крылатых слов и выражений http://dic.academic.ru/dic.nsf/dic_wingwords.

22. Hutton, Paul Andrew. 1999. Phil Sheridan and His Army. p. 180

23. Манойло А.В. Сирийский тупик «Арабской весны». // Вестн. Моск. Ун-та. Сер. 12. Политические науки. 2013. №6. C. 49-56.

24. Манойло А.В. Парадигмы управления международными конфликтами: конкуренция или конфронтация. // Национальная безопасность / nota bene. 2011. № 5. С. 135-142.

25. Манойло А.В.. Роль цветных революций в демонтаже современных политических режимов // Национальная безопасность / nota bene. - 2014. - № 3. - С. 104-107. DOI: 10.7256/2073-8560.2014.3.12058

26. Манойло А.В. Политические конфликты в международных отношениях и мировой политике. //Мир и Политика. 2013. №2. С. 71-82.

27. Гушер А.И. Геополитические и стратегические аспекты операции Воздушно-космических сил России в Сирии // Конфликтология / nota bene. - 2015. - 4. - C. 395 - 402. DOI: 10.7256/2409-8965.2015.4.16967.

28. Бочарников И.В. Террористическая группировка «Исламское государство» как закономерное следствие ближневосточной стратегии США // Тренды и управление. - 2015. - 4. - C. 395 - 402. DOI: 10.7256/2307-9118.2015.4.17007.

29. Фельдман П.Я. Механизмы политического согласования интересов: системный анализ // Конфликтология / nota bene. - 2015. - 4. - C. 416 - 423. DOI: 10.7256/2409-8965.2015.4.17394.

30. Манойло А.В. «Русская весна» в Сирии // Мировая политика. - 2015. - 4. - С. 1 - 26. DOI: 10.7256/24098671.2015.4.17318. URL: http://www.e-notabene.ru/wi/article_17318.html

31. Ласария А.О. Новейший этап формирования абхазской государственности // Конфликтология / nota bene. - 2015. - 4. - C. 430 - 435. DOI: 10.7256/2409-8965.2015.4.17156.

32. Карпович О.Г. Роль интернет-технологий в реализации сценариев цветных революций «Арабской весны» (на примере Египта) // Политика и Общество. - 2015. - 11. - С. 1486 - 1494. DOI: 10.7256/1812-8696.2015.11.16965.

33. Бородинов Е.Н. Анализ крымской внешнеполитической операции // Мировая политика. - 2015. - 1. - С. 81 - 88. DOI: 10.7256/2409-8671.2015.1.12586. URL: http://www.e-notabene.ru/wi/article_12586.html

34. Буневич Д.С. Крымский кризис 2014 года и создание новой архитектуры международных отношений // Конфликтология / nota bene. - 2015. - 2. - C. 133 - 139. DOI: 10.7256/2409-8965.2015.2.14333.

35. Будаев А.В. Основные подходы к использованию «мягкой силы» в интересах реализации внешней политики Российской Федерации // Тренды и управление. - 2014. - 2. - C. 175 - 187. DOI: 10.7256/2307-9118.2014.2.11784.

36. Гушер А.И. Вызовы и угрозы безопасности России // Мировая политика. - 2014. - 1. - C. 64 - 75. DOI: 10.7256/24098671.2014.1.10748. URL: http://www.e-notabene.ru/wi/article_10748.html

37. Карякин В.В. Дефиниция и парадигмы геополитического исследования // Конфликтология / nota bene. - 2015. 4. - C. 382 - 394. DOI: 10.7256/2409-8965.2015.4.17442.

38. Бочарников И.В. Украинский кризис как элемент пояса стратегического окружения России // Мировая политика. 2014. - 4. - C. 7 - 32. DOI: 10.7256/2409-8671.2014.4.11617. URL: http://www.e-notabene.ru/wi/article_11617.html

\section{References (transliterated):}

1. Andreeva E. Bez prolitiya krovi - inkvizitsiya. http://www.bibliotekar.ru/andreeva/12.htm.

2. Bocharnikov I.V. Ostorozhno, totalitarizm http://ria.ru/zinoviev_club/20141030/1030945513.html.

3. V Dubae podschitali stoimost' posledstvii «Arabskoi vesny» http://delovyeemiraty.rf/news/uae-news.php?ELEMENT_ ID $=63334$.

4. Genotsid korennogo naseleniya Ameriki v SShA http://namtaru.ru/genotsid/254.html

5. Gusher A.I. Problema terrorizma na rubezhe tret'ego tysyacheletiya novoi ery chelovechestva http://old.nasledie.ru/ terror/25_8/article.php?art=3.

6. Davidson A.B., Filatova I.I. Anglo-burskaya voina i Rossiya // Novaya i noveishaya istoriya, 2000, №1. http://zadocs.ru/ voennoe/11521/index.html?page=2 
7. Dinnon R. Amerikanskii Indeets: Pervaya Zhertva. http://www.pravda.ru/world/2005/5/82/337/19724_GENOCID.html.

8. Deklaratsiya nezavisimosti. Kongress, 4 iyulya 1776 g. http://www.hist.msu.ru/ER/Etext/indpndnc.htm.

9. Demograficheskaya katastrofa indeitsev Ameriki https://ru.wikipedia.org/wiki.

10. Den' pamyati genotsida armyan v Osmanskoi imperii v 1915 godu http://ria.ru/spravka/20150424/1060167106. html\#ixzz3x8VW0E2U.

11. Litvin A.L. Krasnyi i belyi terror v Rossii. 1918 - 1922 gg. http://www.e-reading.club/bookreader.php/1004379/Litvin_ Aleksey_-Krasnyy_i_belyy_terror_v_Rossii._1918-1922_gg..html\#n_3

12. Lozinskii S. G. Istoriya papstva. 3-e izd. M., 1986. S. 20-21.

13. Lukashevich: Rossiya obespokoena politicheskim ekstremizmom na Ukraine http://www.tvc.ru/news/show/id/82637/.

14. Malyi entsiklopedicheskii slovar': V 4-kh t.: Reprint. vosproizved. izdaniya Brokgauza-Efrona. M: Terra, 1997. T. 4. S. 1891.

15. Masshtaby stalinskikh repressii v otsenkakh sovetskikh i sovremennykh rossiiskikh issledovatelei http://bg.sutr.ru/ journals_n/1356460361.pdf.

16. Natsistskie kontslagerya v gody Vtoroi mirovoi voiny. Spravka. http://ria.ru/spravka/20100427/227000409. html\#ixzz3x8ZSTnOo

17. Na chem stoit Amerika http://www.rospisatel.ru/novosti/nov12.htm

18. Nechiporenko O.M. Terrorizm - drevnii i smertel'no opasnyi sputnik chelovechestva / Mirovoe obshchestvo protiv globalizatsii prestupnosti i terrorizma. Mezhdunarodnaya konferentsiya. M., 2001. Rezhim dostupa: http://www. waaf. ru.

19. Ovsyannikova O.A. Tekhnologii pereformatirovaniya obshchestvennogo soznaniya posredstvom yazykovoi i konfessional'noi diskriminatsii (na primere Ukrainy) // Konfliktologiya / nota bene. - 2015. - № 4. - S.424-429.

20. Odesskii M.F., Fel'dman D.M. Poetika terrora. - M.: RGGU, 1997. - S.54-60.

21. Slovar' krylatykh slov i vyrazhenii http://dic.academic.ru/dic.nsf/dic_wingwords.

22. Hutton, Paul Andrew. 1999. Phil Sheridan and His Army. p. 180

23. Manoilo A.V. Siriiskii tupik «Arabskoi vesny». // Vestn. Mosk. Un-ta. Ser. 12. Politicheskie nauki. 2013. №6. S. 49-56.

24. Manoilo A.V. Paradigmy upravleniya mezhdunarodnymi konfliktami: konkurentsiya ili konfrontatsiya. // Natsional'naya bezopasnost' / nota bene. 2011. № 5. S. 135-142.

25. Manoilo A.V.. Rol' tsvetnykh revolyutsii v demontazhe sovremennykh politicheskikh rezhimov // Natsional'naya bezopasnost' / nota bene. - 2014. - № 3. - S. 104-107. DOI: 10.7256/2073-8560.2014.3.12058

26. Manoilo A.V. Politicheskie konflikty v mezhdunarodnykh otnosheniyakh i mirovoi politike. //Mir i Politika. 2013. S. 71-82.

27. Gusher A.I. Geopoliticheskie i strategicheskie aspekty operatsii Vozdushno-kosmicheskikh sil Rossii v Sirii // Konfliktologiya / nota bene. - 2015. - 4. - S. 395 - 402. DOI: 10.7256/2409-8965.2015.4.16967.

28. Bocharnikov I.V.Terroristicheskaya gruppirovka «Islamskoe gosudarstvo» kak zakonomernoe sledstvie blizhnevostochnoi strategii SShA // Trendy i upravlenie. - 2015. - 4. - S. 395 - 402. DOI: 10.7256/2307-9118.2015.4.17007.

29. Fel'dman P.Ya. Mekhanizmy politicheskogo soglasovaniya interesov: sistemnyi analiz // Konfliktologiya / nota bene. 2015. - 4. - S. 416 - 423. DOI: 10.7256/2409-8965.2015.4.17394.

30. Manoilo A.V. «Russkaya vesna» v Sirii // Mirovaya politika. - 2015. - 4. - S. 1 - 26. DOI: 10.7256/2409-8671.2015.4.17318. URL: http://www.e-notabene.ru/wi/article_17318.html

31. Lasariya A.O. Noveishii etap formirovaniya abkhazskoi gosudarstvennosti // Konfliktologiya / nota bene. - 2015. - 4. S. 430 - 435. DOI: 10.7256/2409-8965.2015.4.17156.

32. Karpovich O.G. Rol' internet-tekhnologii v realizatsii stsenariev tsvetnykh revolyutsii «Arabskoi vesny» (na primere Egipta) // Politika i Obshchestvo. - 2015. - 11. - S. 1486 - 1494. DOI: 10.7256/1812-8696.2015.11.16965.

33. Borodinov E.N. Analiz krymskoi vneshnepoliticheskoi operatsii // Mirovaya politika. - 2015. - 1. - S. 81 - 88 . DOI: 10.7256/2409-8671.2015.1.12586. URL: http://www.e-notabene.ru/wi/article_12586.html

34. Bunevich D.S. Krymskii krizis 2014 goda i sozdanie novoi arkhitektury mezhdunarodnykh otnoshenii // Konfliktologiya / nota bene. - 2015. - 2. - S. 133 - 139. DOI: 10.7256/2409-8965.2015.2.14333.

35. Budaev A.V. Osnovnye podkhody k ispol'zovaniyu «myagkoi sily» v interesakh realizatsii vneshnei politiki Rossiiskoi Federatsii // Trendy i upravlenie. - 2014. - 2. - S. 175 - 187. DOI: 10.7256/2307-9118.2014.2.11784.

36. Gusher A.I. Vyzovy i ugrozy bezopasnosti Rossii // Mirovaya politika. - 2014. - 1. - S. 64 - 75. DOI: 10.7256/24098671.2014.1.10748. URL: http://www.e-notabene.ru/wi/article_10748.html

37. Karyakin V.V. Definitsiya i paradigmy geopoliticheskogo issledovaniya // Konfliktologiya / nota bene. - 2015. - 4. - S. 382 394. DOI: 10.7256/2409-8965.2015.4.17442.

38. Bocharnikov I.V. Ukrainskii krizis kak element poyasa strategicheskogo okruzheniya Rossii // Mirovaya politika. - 2014. 4. - S. 7 - 32. DOI: 10.7256/2409-8671.2014.4.11617. URL: http://www.e-notabene.ru/wi/article_11617.html 